\title{
System Driven Analysis of National Economic Growth: Guangdong as an Example
}

\author{
Yuhan Zhou \\ Institute of Economy, Jinan University, Guangzhou, China \\ Email: zyh2263590@163.com
}

How to cite this paper: Zhou, Y.H. (2017) System Driven Analysis of National Economic Growth: Guangdong as an Example. American Journal of Industrial and Business Management, 7, 27-39.

http://dx.doi.org/10.4236/ajibm.2017.71003

Received: November 8, 2016

Accepted: January 8, 2017

Published: January 11, 2017

Copyright $\odot 2017$ by author and Scientific Research Publishing Inc. This work is licensed under the Creative Commons Attribution International License (CC BY 4.0).

http://creativecommons.org/licenses/by/4.0/

\section{(c) (i) Open Access}

\begin{abstract}
After many years of high-strength construction and large-scale development, it's difficult for Chinese economy to sustain high-speed economic growth only through too much investment and production factors. Economic development is facing a bottleneck. Transformation and upgrading are imminent. Improving innovation becomes an inevitable choice for Chinese economic growth since Chinese economy has been under a new normal macroscopic background. System innovation is the basic content and an important aspect of innovation. There are some intrinsic links between Chinese national economic growth and system changes. This paper selects Guangdong Province as the research object. It analyzes system factors of economic growth in Guangdong Province since the reform and opening up in China. And this paper tries to provide decision-making basis for the innovation of government system in the new normal economy.
\end{abstract}

\section{Keywords}

Economic Growth, System Innovation, Multiple Regression, Guangdong

\section{Introduction}

Since performing the reform and opening up policy, China's average annual economic growth rate has remained close to double-digit growth in ultra highspeed and high-speed. China's economic growth slowed down because of the international financial crisis in 2008. China's economic growth rate further declined to $7.7 \%$ in 2012 and 2013. What's more, its economic growth rate only reached $6.9 \%$ in 2015, showing a further slowing trend. Under the new normal economy, China's economy is facing the worldwide technological innovation and a new wave of industrial revolution. It's important for China to consider 
how to compete with other countries. Studies showed that thanks to the comprehensive effect of system reform, technological progresses and structure optimization, China's TFP level of 2013 was nearly three times higher than that of 1978. As the third industrial revolution is coming, the world will emerge a large number of investment opportunities, new products, new development trends of industry and new business modes. This will undoubtedly become a new impetus to economic development. Chinese companies are showing more willingness to take initiative to transform and enhance innovation under enormous development pressure. The momentum of economic growth is gradually transferring to the new innovation-driven norm. System innovation is an important component of the innovation-driven economic growth. It will have obvious effects on economic development.

As the leader of reform and opening up, Guangdong province has always been playing a very important role in China's economy. Guangdong's GDP was only 18.5 billion in the early period of reforming and opening. It only accounted for $5.1 \%$ of China's GDP. However, Guangdong's GDP rose to 3.0606 trillion after 30 years. It accounted for 1/8 of China's GDP. The average annual GDP growth rate reached 13.5\%. Guangdong Province's GD Preached 6.779224 trillion yuan in 2014 and its GDP ranked the first in the country and accounted for about 10\% of the country's GDP. This mode of growth was called "Zhujiang miracle" by domestic economists. The system has always been playing an important driving role in the process of Guangdong's rapid economic growth and development. After China carried out the reform and opening-up policy, Guangdong province took action rapidly to study new ways to cooperate with Hong Kong and Macao in economy. In 1980, the Central People's Government released a new policy under the requirements of Guangdong province. According to this policy, Guangdong province and Fujian province could implement special policies and flexible measures in their financial institutions. They had more rights to control their financial institutions. At the same time, the Central People's Government established special economic zones in these two provinces. In July 1981, the State Council promulgated several domestic political regulations related to nonagricultural urban individual business. And it established the reform course. The reform course focused on invigorating the economy and opening up the market. In 2008, the National Development and Reform Commission developed a "Pearl River Delta reform and development plan (2008-2020)". In 2014, Guangdong began to explore the innovation of system after Chinese economy has entered a "new normal".

The system of Guangdong Province changes frequently and constantly and its economy also grows quickly, so many scholars are thinking about the connection between system and economic growth. This paper is also considering this question. It is from the perspective of new system economics to consider. This paper has theoretical and empirical analysis on this question by using the economic growth model and econometric tools. This paper also attempts to provide theoretical support for the connection between system innovation and economic 
growth under the new normal economy.

\section{Theoretical Thinking}

\subsection{Research Literature}

At present, the main views of foreign theoretical researches on system-driven analysis of national economic growth can be described as follow:

1) The researches are about the relationship between property rights and transaction costs. Coase (1960) is the leader of the New System Economics. He creatively put forward the relationship between property rights and transaction costs. If transaction costs are more than zero, the system will have influence on economic distribution and change the allocation of resources and the kinds of output products through a lot of researches. So people need make a correct choice between various systems. Different systems will produce different efficiency in resource allocation. Different systems finally result in different kinds of output products. Different systems will produce different transaction costs. Changing system also will produce costs. So choosing a right system needs to think twice. 2) The researches are about the influence of system changes on economic growth. Norce proposed that system changes play a crucial role in economic growth. The essay System changes and economic growth of the United States systematically discussed the relationship between the system changes and economic growth. Its author thought that system was a variable and quantitative index. System change is continuously occurring. And the economy achieves the expected returns because of system change. Systematic equilibrium is the goal of system change. 3) The researches are about the relationship between social system environment and the scale and productivity of capital accumulation. By studying the obvious difference in outputs per capita of different countries, Robert E. Hall and Charles I. Jones (1999) proposed that the scale of capital accumulation and productivity is determined by social system environment which leads to the input discrepancy of resource resulting in different income per capita and economic development, while the quality of social system environment is determined by the incidence of Western civilization in one country [1]. They also measured the effects of western culture by three quantitative index, the distance from the equator, the degree of using western European languages and the trade share ( $F \& \mathrm{R})$.

In domestic theoretical circles, the representative points are as follow: Wang Jun (2013) and other researchers found that the steady-state economic growth rate depended on the system correction coefficient, population growth rate and the contribution rates of system in the macro-production function. It's necessary to reform and implement system change in order to achieve stable and sustainable economic growth. Wu Jinglian (2006) proposed that system was more important than technological evolution. The development speed of high-tech industry was not determined by money and labor in a country or a region. It depended on a series of system arrangements, social environment and cultural atmosphere. The atmosphere can make contribution to the promotion of innovative 
activities and bring human's potential into full play. Ding Huixia (2012) chosen 28 regions of China and did empirical test by using their panel data from 1992 to 2008. According to the results, he found that system factors had an impact on economic growth and the patterns of growth [2]. Liu Yuke and Kuang Xiangming (2012) selected the economic system, political system, legal system and comprehensive system as indicators. They used the data of Hunan province to make empirical analysis. They found that the connection among these various systems was not particularly tight. But they also found that the system factors actually had great contribution to promoting economic growth [3].

It can be seen from the literature mentioned above: There are many domestic and foreign researches about the relationship between system and economic growth. The theory and economic models are also gradually improved. But the system is a quite complex factor comparing with other factors of economic growth. And there are a lot of disputes about making quantitative analysis on system in theoretical circles. The choice of system factors is largely individualized by scholars' subjective consciousness. This paper intends to break through the shortcomings of the existing researches. It takes the new normal state of national economic development as the premise. It also takes Guangdong as an example to analyze the contribution made by system innovation to the national economic growth.

\subsection{The Path System Affects Economic Growth}

\subsubsection{The Changes of System Will Affect Sustainable Economic Growth}

The impetus of system change will be revised in a certain period of time after the occurrence of system changes from external and internal, because there exists such a cumulative dynamic correction process. System change will have a positive effect on economic growth. If the system is lack of adjustment and amendment, the system change will not play a role in long-term economic growth.

Therefore, it can be argued that system change has not a final goal. The reform can not be suspended. If a society loses the impetus to reform, its economy will stall [4]. System change is really a significant factor in receiving the goal of sustainable economic growth.

\subsubsection{System Innovation Will Promote Technological Innovation So as to Facilitate Long-Term Economic Growth}

System innovation is like a bridge which connects technological innovation with industrial innovation. Technological innovation can not automatically expand into industrial innovation. The system innovation provides a path for the technology to diffuse and transfer. And it makes the industry innovation become a reality. What's more, system innovation promotes economic growth by increasing economic activities and reducing transaction costs [5]. If the system has higher contribution rate in the macro-production function, the rate of economic growth will be higher. The contribution rate of system is positively related to the rate of economic growth. Therefore, it is significant to improve the contribution rate of these two systems. 


\subsubsection{System Regularization Will Affect Steady Economic Growth}

The system plays its role in the steady growth of the economy mainly through the formal system, the informal system and the formal realization mechanism and the informal realization mechanism. The formal system, such as constitution, law, property rights and other system variables have an impact on realizing stable economic growth of one country through the formal realization mechanism, while the informal system has different degrees of effects on achieving stable economic growth through a number of informal mechanisms [6]. If the system change lacks stable rules, the random supply of system will lead to dramatic fluctuations in the rate of economic growth. Finally, the rate of economic growth can not enter steady-state growth path. The introduction of any reform measures must follow the systematic rules and keep in line with the normative and reasonable procedures. Only by these methods can the economic growth maintain steady.

\section{Empirical Analysis}

\subsection{Setting of the Measurement Model}

In order to estimate the contribution of each factor to economic growth, this paper establishes the expanded CD production function. The function includes the factors of system change and divides the capital into material capital and human capital by adopting the empirical model. This model proposed by Liu Zunyi (1989):

$$
Y_{t}=A_{t} W_{t}^{a} L_{t}^{b} R_{t}^{c} Z_{t}^{d}
$$

In this equation, $Y$ means the total output; $\mathrm{L}$ means the labor input; $W$ means the input of material capital; $R$ means the human capital stock; $Z$ means the system variable; $A$ mean other factors affecting economic growth. They include technological progress. $a, b, c, d$ are respectively the output elasticity of physical capital, labor force, human capital and institutional factors.

In order to facilitate the OLS regression, the logarithmic form of the equation is made: $e=\operatorname{LnAt}$ It is regarded as the constant term.

$$
L n Y t=e+a L n W t+b L n L t+c L n R t+d L n Z t
$$

\subsection{Index Selection and Data Processing}

\subsubsection{Gross Output $Y$}

In this paper, GDP is used as the basic index to measure the gross output.

\subsubsection{Labor Input $\mathrm{L}$}

The most accurate way to measure the labor input should be the "service flow" provided by labor within a certain period of time. It is determined by the input of factors. And it is related to the usage efficiency of factors, quality of the factors and other factors. Moreover, the annual population mobility of Guangdong is also very huge. The amount of labor input of the migrant workers is considerable. This paper uses the number of employees in the previous years as an indicator of labor input, because it is lack of relevant statistical data. 


\subsubsection{Material Capital Input.}

In the current statistics, there is no stock index for material capital of the whole social. So it is estimated by adopting the "perpetual inventory method". It assumes the fixed depreciation rate is $5 \%$. Thus we can obtain the data of material capital input indicators in Guangdong from 1978 to 2013 by selecting the value of the material capital stock of Guangdong province in 1978. This is calculated by Wang Bing (2002) as the first phase K1 and through the formula

$$
\mathrm{K}(\mathrm{t})=\mathrm{K}(\mathrm{t}-1)(1-\delta)+\mathrm{I}(\mathrm{t})(\mathrm{t}=2, \cdots, 35) .
$$

\subsubsection{Gross Human Capital Input}

There is no unified measurement gauge for human capital. The founder of new economic growth theory, Lucas (1988) proposes that the way to measure human capital was based on the level of education of labors. However, Rohmer (1986) used the number of researchers to measure the human capital. Due to some limitations, Lucas's method is more suitable to use. Because the values created by workers of different educational level are different. It is necessary to consider the degree of education. The specific formula is: the total amount of human capital $=$ the number of higher schools $\times 16+$ the number of secondary school $\times 12+$ the number of primary school $\times 6$. The secondary schools include the secondary technical schools, secondary normal schools, schools for technical workers, ordinary secondary schools, agricultural vocational schools (the data can be seen from Table 1).

\subsubsection{System Factors}

1) The system factors are seldom included in the model of empirical analysis because they are difficult to be quantified and different researchers carry out studies from different perspectives. So the selection of relevant indicators is different as well. On such basis, this paper takes the system changes since the reform and opening up in Guangdong and selects different indicators to measure from four aspects: the change of property right system, the improvement of the degree of marketization, the pattern of the income distribution and the degree of opening according to the research results of Jin Yuguo (2001) [7], Wang Bing (2004) [8], Zhong Xingtao (2008) [9] and other researchers. The change of property right system is mainly manifested by the non-nationalization of economic elements. It means that how many economic resources are not controlled by country. The non-nationalization rate can be used to indicate the degree of diversification of ownership. That is to say: the degree of ownership diversification $\left(\mathrm{X}_{1}\right)=$ the production value of non-state owned industrial enterprises/the total production value of industrial enterprises [10]. The index of marketization is to reflect the breadth and depth of the resources allocated by economy itself. Due to the lack of statistical data, this paper only investigates the degree of marketization of production factors. And the marketization index of investment is used as a representative. It is the proportion of three indicators. They are respectively foreign investment, self-investment and other investment because the scales of these three investments are basically determined by the market and 
Table 1. Guangdong's basic economic data (1978-2013).

\begin{tabular}{|c|c|c|c|c|}
\hline Year & $\begin{array}{c}\text { GDP } \\
\text { (billion yuan) }\end{array}$ & $\begin{array}{c}\text { Labor } \\
\text { (ten thousand people) }\end{array}$ & $\begin{array}{l}\text { Material capital } \\
\text { (billion yuan) }\end{array}$ & $\begin{array}{l}\text { Human } \\
\text { capital }\end{array}$ \\
\hline 1978 & 185.8467 & 2275.95 & 191.8630 & 8310.76 \\
\hline 1979 & 201.5420 & 2304.95 & 209.7359 & 7810.90 \\
\hline 1980 & 235.0558 & 2367.78 & 233.4977 & 7678.76 \\
\hline 1981 & 256.2079 & 2423.79 & 271.3310 & 7194.84 \\
\hline 1982 & 286.8436 & 2521.38 & 325.6028 & 6895.90 \\
\hline 1983 & 307.7473 & 2569.70 & 379.8954 & 6830.64 \\
\hline 1984 & 355.6622 & 2637.49 & 463.3928 & 7060.18 \\
\hline 1985 & 419.4659 & 2731.11 & 567.9671 & 7210.26 \\
\hline 1986 & 472.9418 & 2811.92 & 682.4730 & 7435.20 \\
\hline 1987 & 565.7923 & 2910.99 & 796.7004 & 7595.66 \\
\hline 1988 & 655.1672 & 2994.72 & 917.3693 & 7625.04 \\
\hline 1989 & 702.2379 & 3041.27 & 1001.786 & 7722.98 \\
\hline 1990 & 783.4697 & 3118.10 & 1101.410 & 7788.14 \\
\hline 1991 & 922.0007 & 3259.20 & 1232.845 & 8214.42 \\
\hline 1992 & 1125.875 & 3367.21 & 1510.956 & 8552.36 \\
\hline 1993 & 1377.217 & 3433.91 & 1943.789 & 9014.28 \\
\hline 1994 & 1639.929 & 3493.15 & 2408.139 & 9630.58 \\
\hline 1995 & 1885.015 & 3551.20 & 2834.541 & 10236.78 \\
\hline 1996 & 2085.76 & 3641.30 & 3216.704 & 10809.20 \\
\hline 1997 & 2306.268 & 3701.90 & 3572.653 & 11282.32 \\
\hline 1998 & 2540.728 & 3783.87 & 4012.502 & 11634.08 \\
\hline 1999 & 2782.1 & 3796.32 & 4537.736 & 12065.28 \\
\hline 2000 & 3082.563 & 3989.32 & 5086.875 & 12341.38 \\
\hline 2001 & 3378.488 & 4058.63 & 5692.344 & 12958.92 \\
\hline 2002 & 4001.908 & 4134.37 & 6387.902 & 13735.18 \\
\hline 2003 & 4596.071 & 4395.93 & 7310.317 & 14687.38 \\
\hline 2004 & 5275.724 & 4681.89 & 8390.119 & 15554.88 \\
\hline 2005 & 6020.982 & 5022.97 & 9658.669 & 16387.94 \\
\hline 2006 & 6912.505 & 5177.02 & 11063.47 & 17055.18 \\
\hline 2007 & 7940.060 & 5341.50 & 12664.98 & 17398.24 \\
\hline 2008 & 8768.589 & 5471.72 & 13316.47 & 17684.30 \\
\hline 2009 & 9614.764 & 5688.62 & 14059.36 & 18028.62 \\
\hline 2010 & 10811.824 & 5870.48 & 15940.50 & 18646.54 \\
\hline 2011 & 11891.612 & 5960.74 & 17885.78 & 18615.84 \\
\hline 2012 & 12861.376 & 5965.95 & 18872.89 & 18314.20 \\
\hline 2013 & 13953.370 & 6117.68 & 20867.70 & 17828.48 \\
\hline
\end{tabular}

The data is from the "Guangdong Statistical Yearbook 2014".

determined independently by investors. The specific proportion can reflect the degree of marketization in the investment field and its formula is: the marketization index of the production factors $\left(\mathrm{X}_{2}\right)=$ (the amount of investment used by foreign capital and domestic capital + the amount of other investment)/total social investment in fixed assets. The changes of the income distribution pattern 
are measured by the proportion of market income distribution to GDP. It will reflect the scale of the market share in the distribution of economic benefits. Its formula can be expressed as follow: the marketization index of income distribution $\left(\mathrm{X}_{3}\right)=$ (GDP of the calculated year-national financial revenues)/GDP of the calculated year. As for the degree of openness, it can be expressed by the degree of dependence on foreign trade. The degree of openness $\left(\mathrm{X}_{4}\right)=$ total amount of import and export/GDP. This paper attempts to carry out the principal component analysis to the four variables by using the multivariate statistical method and the statistical software SPSS16.0. And then they will be integrated into one indicator. This score indicator of principal component is used to express the system factors.

2) Before making the principal component analysis of system factors, the $\mathrm{KMO}$ and Bartlett spherical test is made for the four variables. When $\mathrm{KMO}=$ 0.777, the significant probability of statistic value for Bartlett spherical test $\chi^{2}$ is 0.000 . It is less than $1 \%$ and is suitable for principal component analysis. The principal component $\mathrm{F} 1$ whose characteristic value is more than 1 is extracted. Its final characteristic value is 3.436 and its contribution rate is $85.9 \%$. The scores of the first principal component for four variables are respectively: 0.925, $0.968,0.878,0.934$. According to the scores of principal component, the computational formula can be $F_{1}=\frac{0.925 X_{1}+0.968 X_{2}+0.878 X_{3}+0.943 X_{4}}{\sqrt{3.436}}$ this is index $\mathrm{Z}$ for the system factor (the index can be seen from Table 2).

\subsection{Multiple Regression Analysis}

\subsubsection{Data Stability Test}

Logarithm is taken for $\mathrm{Y}, \mathrm{L}, \mathrm{W}, \mathrm{R}, \mathrm{Z}$ after data procession. So LnY, LnL, LnW, LnR, LnZ are obtained. Then LnY is taken as the dependent variable. The rest four factors are the independent variables for multiple regression. In order to avoid spurious regression, the first five variables are used to carry out stability test. After the unit root test, it is known that $\ln (\mathrm{Y}) \sim \mathrm{I}(2), \ln (\mathrm{L}) \sim \mathrm{I}(2), \ln (\mathrm{W}) \sim$ $\mathrm{I}(2), \ln (\mathrm{R}) \sim \mathrm{I}(2)$ and $\ln (\mathrm{Z}) \sim \mathrm{I}(2)$. The five variables are all 2-order single integration. On such basis, the Johansen co-integration test of multiple regression is carried out. It can be seen that there is a co-integration relationship among the five variables in the model under $99 \%$ confidence level.

\subsubsection{OLS Regression}

$$
L n Y=-8.477+0.951 L n L+0.641 L n W+0.330 L n R+0.04 L n Z
$$

After the stability test, OLS regression is made for the 5 variables. The following regression equation is obtained by using Eviews 6.0:

$$
L n Y=-8.477+0.951 L n L+0.641 L n W+0.330 L n R+0.04 L n Z
$$

$(-6.62)(5.33)(12.08)(3.54)(0.48)$

$\mathrm{R} 2=0.999 \mathrm{~F}=9230.853 \mathrm{DW}=0.682$

The overall co-integration level of the equation is very high. It indicates that the explanatory power of the equation is very strong. Moreover, under the significant level $\alpha=0.05$, the equations generally pass the $\mathrm{F}$ test. Each explanatory 
variable ( $t$ value in brackets) passes the $\mathrm{T}$ test in the higher significant level. According to the regression results and Table 2 , the Thoreau growth equation can be used to calculate for each factor's contribution share and rate of economic growth. The results are shown in Table 3.

Table 2. The system variable of Guangdong's economy and the scores of the principal component (1978-2013).

\begin{tabular}{|c|c|c|c|c|c|}
\hline Year & $\begin{array}{l}\text { The degree of } \\
\text { ownership } \\
\text { diversification X1 }\end{array}$ & $\begin{array}{l}\text { The } \\
\text { marketization } \\
\text { index of the } \\
\text { production } \\
\text { factor X2 }\end{array}$ & $\begin{array}{c}\text { The } \\
\text { marketization } \\
\text { index of } \\
\text { income } \\
\text { distribution X3 }\end{array}$ & $\begin{array}{l}\text { The degree of } \\
\text { opennessX4 }\end{array}$ & $\begin{array}{c}\text { The scores of } \\
\text { the principal } \\
\text { component of } \\
\text { system } Z\end{array}$ \\
\hline 1978 & 0.276064 & 0.394 & 0.775 & 0.143858 & 0.779091 \\
\hline 1979 & 0.272917 & 0.403 & 0.827 & 0.144004 & 0.806711 \\
\hline 1980 & 0.314490 & 0.426 & 0.849 & 0.153265 & 0.854428 \\
\hline 1981 & 0.321400 & 0.485 & 0.859 & 0.157399 & 0.895330 \\
\hline 1982 & 0.324672 & 0.473 & 0.876 & 0.170002 & 0.905017 \\
\hline 1983 & 0.316658 & 0.597 & 0.880 & 0.178090 & 0.971414 \\
\hline 1984 & 0.339129 & 0.635 & 0.893 & 0.183082 & 1.011016 \\
\hline 1985 & 0.366909 & 0.671 & 0.880 & 0.346557 & 1.119253 \\
\hline 1986 & 0.401283 & 0.685 & 0.877 & 0.379441 & 1.158752 \\
\hline 1987 & 0.436670 & 0.708 & 0.887 & 0.924277 & 1.465523 \\
\hline 1988 & 0.474278 & 0.695 & 0.907 & 0.999300 & 1.524479 \\
\hline 1989 & 0.492216 & 0.772 & 0.901 & 0.969916 & 1.555976 \\
\hline 1990 & 0.482688 & 0.788 & 0.916 & 1.285620 & 1.724434 \\
\hline 1991 & 0.550822 & 0.765 & 0.906 & 1.476543 & 1.837303 \\
\hline 1992 & 0.585065 & 0.782 & 0.909 & 1.481462 & 1.867134 \\
\hline 1993 & 0.664269 & 0.790 & 0.900 & 1.301163 & 1.816516 \\
\hline 1994 & 0.718554 & 0.839 & 0.935 & 1.803651 & 2.136833 \\
\hline 1995 & 0.779240 & 0.905 & 0.936 & 1.463393 & 2.031837 \\
\hline 1996 & 0.798027 & 0.889 & 0.930 & 1.336209 & 1.966498 \\
\hline 1997 & 0.816494 & 0.907 & 0.930 & 1.387422 & 2.010698 \\
\hline 1998 & 0.850718 & 0.887 & 0.925 & 1.259657 & 1.951178 \\
\hline 1999 & 0.712884 & 0.823 & 0.917 & 1.256134 & 1.843459 \\
\hline 2000 & 0.749528 & 0.852 & 0.915 & 1.311025 & 1.895638 \\
\hline 2001 & 0.769393 & 0.860 & 0.904 & 1.213365 & 1.863459 \\
\hline 2002 & 0.800687 & 0.876 & 0.911 & 1.355297 & 1.961682 \\
\hline 2003 & 0.816439 & 0.908 & 0.917 & 1.481076 & 2.051908 \\
\hline 2004 & 0.795660 & 0.916 & 0.925 & 1.566932 & 2.092366 \\
\hline 2005 & 0.822620 & 0.909 & 0.919 & 1.567549 & 2.099695 \\
\hline 2006 & 0.837645 & 0.926 & 0.917 & 1.554288 & 2.108477 \\
\hline 2007 & 0.844281 & 0.988 & 0.910 & 1.517198 & 2.122199 \\
\hline 2008 & 0.829659 & 0.902 & 0.910 & 1.290039 & 1.956589 \\
\hline 2009 & 0.841963 & 0.960 & 0.908 & 1.057314 & 1.898338 \\
\hline 2010 & 0.846590 & 0.948 & 0.902 & 1.154749 & 1.938912 \\
\hline 2011 & 0.853194 & 0.972 & 0.896 & 1.108628 & 1.926145 \\
\hline 2012 & 0.887904 & 0.953 & 0.891 & 1.088381 & 1.902473 \\
\hline 2013 & 0.961180 & 0.974 & 0.886 & 1.087824 & 1.947402 \\
\hline
\end{tabular}

The data are from the "Guangdong Statistical Yearbook 2014". 
Table 3. The calculating results of factor contributed to Guangdong's economic growth (1978-2013).

\begin{tabular}{ccccc}
\hline & $\begin{array}{c}\text { Average annual } \\
\text { growth rate (\%) }\end{array}$ & $\begin{array}{c}\text { Coefficient of } \\
\text { elasticity (\%) }\end{array}$ & $\begin{array}{c}\text { Share of the } \\
\text { contribution (\%) }\end{array}$ & $\begin{array}{c}\text { The contribution } \\
\text { rate (\%) }\end{array}$ \\
\hline GDP (Y) & 13.272 & & & 100 \\
Labor input (L) & 2.875 & 0.951 & 2.734 & 20.014 \\
Material capital (W) & 14.731 & 0.641 & 9.443 & 71.150 \\
Human capital (R) & 3.111 & 0.330 & 1.027 & 7.738 \\
System change (Z) & 2.577 & 0.04 & 0.103 & 0.776 \\
$\begin{array}{c}\text { Technology } \\
\text { advancement }\end{array}$ & & & 0.068 & 0.322 \\
\hline
\end{tabular}

\subsubsection{The Analysis of Empirical Results}

1) Economic growth is pulled by investment. From Table 3, the material capital investment made the largest contribution to the economic growth of Guangdong. For each additional point of material capital investment, GDP increases by 0.641 point. Its contribution rate of economic growth is $71.150 \%$. This is the main source of economic growth in Guangdong. In terms of annual growth rate, the average annual growth rate of physical capital is $14.731 \%$ which is higher than the average annual growth rate of GDP. It indicates that Guangdong pushes its economic growth by investing a large amount of resources. So it is still necessary to maintain a high level of savings and investment to promote the sustained and rapid economic growth of Guangdong in the short term.

2) The input of labor is at a low level. The contribution of human capital is very low in Guangdong. If the labor input increases by one point, the GDP will increase by 0.330 point. There are some defects in the measurement of human capital. So the results are not quite good. The measurement ignores the roles of education and scientific research ability. These results underestimated the contribution of human capital. The input of labor increases one point, GDP will increase by 0.951 point. Its contribution to economic growth is $20.014 \%$. In Guangdong, especially in the Pearl River Delta region, a large number of laborintensive industries exert a profound effect on the economic growth. In fact, the labor of Guangdong is mostly floating population. They are not permanent resident population. To a certain extent, this will underestimate the contribution made by labor to economic growth. So we believe that the advantages of labor resource in Guangdong are obvious. But the quality of labor is very low. If the investment in human capital can be increased, the economic development of the region will be further promoted.

3) The contribution of technology is small. From 1978 to 2013, the contribution made by technological progress to economic growth in Guangdong is 0.068 point. And the contribution rate of technology is only $0.322 \%$. Comparing with the physical capital and labor input, the proportion is very low. There is a long way to accelerate technological progress and improve the innovation in Guangdong. 
4) The effect of system factors is not obvious. In multiple regressions, system factors have little influence on the growth of GDP. The elastic coefficient is 0.04 . Its contribution to economic growth rate is only 0.776 . This result is opposite to the reality. The general system changes greatly promote the economic growth in reality. In this regard, we believe that it is difficult to quantify the system factors. The system factor used by multiple regressions is composed of four indexes. The four indexes are synthesized by the method of principal component analysis. In this process, the loss of information and the distortion of data are inevitable. On the other hand, it also shows that the system changes have an effect on economic growth in Guangdong. But the effect is not prominent and not direct. Good system changes improve all kinds of environment which is conducive to the rapid development of economy, such as investment environment. In addition, there is another reason for this result. China's economy has entered a new stage, the economy new normal. The new normal of economy requires that the growth rate of the economy transfers from high speed to medium high speed. China begins to put focus on the quality of economic growth. Guangdong province also conforms to the current domestic economic situation and adjusts its economic growth rate. In the 2015 work reports from Guangdong's government, the expected growth rate of GDP in Guangdong Province in 2015 was about 7.5\%. The growth rate had decreased significantly relating to the previous few years. The speed of economic growth is slowing down. The industries are in the transition of upgrading. Not only Guangdong province but also the whole country has experienced the pressure from countries' worse economic condition.

\section{Conclusion and Suggestion}

Through the analysis of regression equation, we found the problems and defects hidden behind the rapid growth of many years of Guangdong's economy. Guangdong has attracted a large number of foreign investments and foreign labor by the geographical and political advantages. These have driven the rapid economic growth after the reform and opening up. However, most processing trade is largely limited to manual and machine manufacturing with low technology under the exogenous economy. Although these industries can really promote the economic growth in Guangdong, it is difficult for them to become inexhaustible motive force in the sustainable development. Guangdong's economic growth is driven by high energy consumption and investment. This method of growth is bound to be limited by the resources and is difficult to continue. From this level, the so-called Guangdong model is a typical representative of the "East Asian resource consumption economic growth" proposed by Krugman and Liu Zunyi. International experience shows that land, capital and other traditional factors of production will make less and less contribution to economic growth rate in the developing stage when GDP per capita exceeds 3000 US dollars while the importance of technology will increase significantly. Technological innovation and system gradually become the core driving force of economic development [11]. To this end, the following measures can be taken in order to 
promote the national economy to continuously grow:

1) Implementing the system innovation firmly. The system is an important factor to promote the efficiency of technology, labor and capital. The government should firmly implement reasonable policies and establish a good system environment. And the government should pay attention to the current situation of the development of the province's economy. It also should estimate its future development and conduct the system innovation on science and technology, policy and environment in accordance with the province's situation within the framework of national basic system. At the same time, system reform should be regularized and stabilized to avoid shaky institution changes. So the economic entity can establish the stable expectation in the process of system changes. Through the firm system innovation, the rule of supplying system should regard meeting the requirements of system demanders as a starting point.

2) Perfecting the modern property rights system. China's economic development practice shows that the private ownership economic development is better, the economic development is healthier. Therefore, improving the modern property right system is conducive to the realization of improving the economic growth rate and quality. Since the reform and opening up, the number of private ownership enterprises is growing constantly in Guangdong province. Until February 2015 , there were 2,034,800 private enterprises in Guangdong province. The average annual growth rate reached $29.72 \%$. The amount of average registered capital of enterprises was 4,042,900 yuan. Compared with the same period in 2014 and in 2013, it respectively increased by $30.17 \%$ and $62.78 \%$. Private ownership enterprises accounted for $87.35 \%$ of the total number of enterprises in Guangdong Province. This amount respectively increased by $2.51 \%$ and $4.98 \%$ compared with the same period in 2014 and 2013. This shows that private ownership enterprises have played a great role in economic growth of Guangdong. Therefore, perfecting modern property right system and giving full play to the incentive function of property rights are conducive to the realization of improving the economic growth rate and quality.

3) Promoting technological innovation through system innovation. A good innovation mechanism is an important system to improve the efficiency of capital, labor and other factors. However, the externality of technological innovation activities is very high. Large amount of initial investment may lose because of long period of research and development, shortage of funds and researchers. The function of enterprises and market is always faint, so the function of government is greatly significant. The government should attach great importance to technological innovation. It should increase the investment capital in the stage of technology research and development [12] and build a good platform for promoting the circulation of talents' information. Besides, through the circulation of information in the platform, enterprises in the same industry can share and enjoy the results of research and development together. This works pretty well especially for small and medium-sized enterprises, for it can solve the problem of lack of technical innovation ability. 


\section{References}

[1] Hall, R.E. and Jones, C.I. (1999) Why Do Some Countries Produce So Much More Output per Worker than Others? Quarterly Journal of Economics, 114, 83-116. https://doi.org/10.1162/003355399555954

[2] Ding, H.X. (2012) System and China's Economic Growth: An Analysis Based on the Analysis on Transforming the Way of Economic Growth. Journal of Zhengzhou University (Philosophy and Social Sciences), No. 1, 77-80.

[3] Liu, Y.K. and Kuang, X.M. (2012) System Change and Regional Economic Growth: An Empirical Study Based on the Data from Hunan Province. Economic Geography, No. 32, 25-29.

[4] Wang, J., Zou, G.P. and Shi, X.J. (2013) The Impact of System Change on China's Economic Growth: An Empirical Study Based on VAR Model. China Industrial Economy, No. 6, 70-82.

[5] Tang, C.A. and Yang, O. (2013) System Change, Technological Progress and Economic Growth of Big Developing Countries. Hunan Social Sciences, No. 1, 61-64.

[6] Xu, Y.D. (2014) Research on the System Factors and Paths of Transforming Economic Development Mode under New Norms. Explore, No. 5, 108-113.

[7] Jin, Y.G. (2001) The Contribution of Macro System Change to China's Economic Growth in the Period of Transition. Finance and Economics, No. 2, 24-28.

[8] Wang, B. (2004) Guangdong's Economic Growth Model with System Factors and Empirical Analysis. Journal of Jinan University, No. 3, 6-10.

[9] Zhong, X.T. and Gong, W.P. (2008) An Empirical Study of the Impact of System Factors on Factor Efficiency in Guangdong's Economic Growth. South Economy, No. $4,75-81$.

[10] Wang, W.B., Chen, C.B. and Xu, H.Y. (2002) China's Economic Growth Model with System Factors and Empirical Analysis. Modern Economy and Science, No. 2, 33-37.

[11] Liu, Z.Y. (1997) The Source and Prospect of Economic Growth in East Asia. Quantitative, Technical and Economic Research, No. 10, 88-97.

[12] Bi, Z.X. (2015) Technology Diffusion in Economic Growth: A Comparison between China and South Korea. Science \& Technology Progress and Policy, No. 2, 24-29.

\section{Scientific Research Publishing}

\section{Submit or recommend next manuscript to SCIRP and we will provide best service for you:}

Accepting pre-submission inquiries through Email, Facebook, LinkedIn, Twitter, etc. A wide selection of journals (inclusive of 9 subjects, more than 200 journals)

Providing 24-hour high-quality service

User-friendly online submission system

Fair and swift peer-review system

Efficient typesetting and proofreading procedure

Display of the result of downloads and visits, as well as the number of cited articles

Maximum dissemination of your research work

Submit your manuscript at: http://papersubmission.scirp.org/

Or contact ajibm@scirp.org 